\title{
Biodiversity in the Neotropics: ecological, economic and social values
}

\author{
Tundisi, JG. * and Matsumura-Tundisi, T. \\ Instituto Internacional de Ecologia - IIE, \\ Rua Bento Carlos, 750, Centro, CEP 13560-660, São Carlos, SP, Brazil \\ *e-mail: tundisi@iie.com.br \\ Received September 30, 2008 - Accepted September 30, 2008 - Distributed November 30, 2008
}

\begin{abstract}
Biodiversity in the neotropical region is of enormous importance, specially related to the future exploitation of this natural resource for food production, medical applications and restoration ecology and technology. Knowledge of this biodiversity and its conservation represents an important step from the scientific and applied point of view. Neotropical biodiversity is endangered by human interventions. Loss of this large genetic and phenotypic base will affect the functioning of freshwater and terrestrial ecosystems. Neotropical forests and floodplains, great internal deltas of rivers are active centers of evolution.

Loss of neotropical biodiversity will represent the loss of processes, economic values and ecosystem services.
\end{abstract}

Keywords: Neotropics, economy, biodiversity, climatic changes, processes.

\section{Biodiversidade no Neotrópico: valores ecológicos, econômicos e sociais}

\begin{abstract}
Resumo
Biodiversidade na região tropical tem uma enorme importância especialmente relacionada com a exploração racional desse recurso natural para produção de alimentos, fibra e produtos farmacêuticos.

O conhecimento desta biodiversidade e a sua importância e mecanismos de funcionamento tem uma relevância fundamental para a conservação. A biodiversidade neotropical está sendo ameaçada por inúmeras intervenções humanas. Florestas, rios, lagos, áreas alagadas da região neotropical são "centros ativos de evolução". A perda da biodiversidade e a perda desses processos naturais causarão alterações irreversíveis nos mecanismos de funcionamento destes sistemas agravada pelo impacto das mudanças climáticas.

Quanto vale a biodiversidade da região neotropical? Estas questões e o futuro da conservação poderão ser encaminhados com aportes de conhecimentos da ciência e aplicação de tecnologias para reverter tendências e promover inovações.
\end{abstract}

Palavras-chave: Neotropicos, economia, biodiversidade, mudanças climáticas, processos.

\section{Introduction}

From the "biospheric membrane that covers the planet Earth" (Wilson, 2002) the neotropics have an immense importance. Biodiversity in the neotropics is a large repository of genetic information. In the neotropical forests, lakes, rivers and wetlands there are the greatest number of plants and animals on planet Earth. The Atlantic Tropical Forest, despite the reduction of its extension over the last 20 years, is still one of the greatest global reserves of biodiversity. (Wilson, 2008).

Neotropical biodiversity has an enormous economic importance besides its ecological relevance. There is a strong human dependence on biodiversity. As the Millenium Ecosystem Assessment project showed (MEA 2003) food, fibre, pharmaceuticals, climate regulation, water purification - all these services are provided by a complex network of species, populations, communities and ecosystems in the neotropics. For Margalef (1998),

the large floodplains, great internal deltas of the Amazon region, "are active centers of evolution". This has been demonstrated in several research works and in many projects developed in the Amazon Region.

To protect, exploit rationally and to recover biodiversity, it is necessary to improve knowledge on neotropical biodiversity.

Despite much effort that has resulted in papers and publications (see the article by Haffer in this volume), even more is necessary to better understand the mechanisms of interactions and the complex conditions that sustain this biodiversity in the neotropics.

\section{How Much is Neotropical Biodiversity Worth?}

The fundamental paper of Constanza et al., 1997 showed the economic value of the services of the eco- 
logical systems and the natural capital stocks that contribute to human welfare directly and indirectly. By the calculations of these authors, tropical forests would be worth U\$ 2,007 per ha ${ }^{-1} /$ year! But in the neotropics, forests are not the only ecosystem. Wetlands, floodplains, lakes and rivers add a very high value to neotropical biodiversity (the Amazon basin has more fish species than the Atlantic Ocean). The enormous variety of habitats, biological properties, genetic biodiversity in the neotropics have a high economic value.

But a major asset is the capacity to sustain the permanent evolutive capacity of this vast complex of species, populations and communities that adds high flexibility to the neotropical ecosystems. This is considered by Dumont (2005) who emphasized that "assigning monetary values to non domesticated biodiversity derived from economic theory fail to capture the true values of ecosystem components and their services" (apud Dumont, H., 2005). According to this author, the "risk of extinction" concept and the "international security" avenue should be considered. Another possible avenue to consider is the "exploration value" of biodiversity.

In any case, biodiversity in the neotropics is an enormous economic asset that should be considered as part of the Gross National Product of the countries that share this biodiversity.

Knowledge of this biodiversity should undoubtedly add new economic opportunities and richness by opening up possibilities of adequate exploitation for such products as new pharmaceutics, biofuels and food supply.

Research on neotropical biodiversity can also add new knowledge necessary for conservation of large areas that are fundamental to sustain natural processes, purify water, stabilize soil and provide a buffer against global changes.

\section{Economic Development and Neotropical Biodiversity}

Economic growth and the pattern of development can have a very high impact on biodiversity. Biofuel production $(70 \%$ of the soil use in São Paulo State is dedicated to sugar cane production), hydroelectricity, expansion of mining activities, expansion of the agricultural frontier - all these undertakings will affect species, populations, communities and ecosystems. Changes can be catastrophic for neotropical biodiversity. Guimarães and Toledo (this volume) discuss the impact of deforestation and threats to biodiversity in Amazonia, and Alho (this volume) discusses the response of the Pantanal lakes, rivers and the communities to the environmental degradation.

The restoration of biodiversity (see Mendiondo, this volume) specially in the urban region, is another important approach to biodiversity conservation: How much is needed to restore an impacted region? What processes do we know that are fundamental for restoration technologies? Human intervention is endangering the species diversity and processes in the neotropics. How to keep a balance between development, biodiversity conservation and exploitation in the tropics? Zalewski (2007) proposes the ecohydrology concept as a basis for the preservation of biodiversity and using "natural capital" and natural processes to control impacts and their effects on ecosystems. This probably is one of the possibilities for conservation of biodiversity in the neotropics.

\section{Biodiversity and Climatic Changes}

Knowledge of biodiversity in the neotropics is fundamental to understand key processes and the responses to degradation and climatic changes. Marengo (2008) discusses the impact of climatic changes in South America and Marengo (2007) showed the impact of climatic changes on neotropical biodiversity.

The possibilities of drastic hydrologic changes in Amazonia, for example, can reduce the water volume of rivers and lakes with enormous consequences for aquatic and terrestrial biodiversity.

Economic impacts of this biodiversity reduction in the neotropics may be severe; they refer not only to present loss but on the future loss of processes, interactions and evolutionary mechanisms.

Impacts on the regional economy of large areas of the neotropics can be expected, by climatic changes.

\section{Conclusions}

As Wilson (2002) states "we are inside a bottleneck of overpopulation and wasteful consumption" (apud Wilson 2002). We could also add that there is a path of overexploitation and increased use of energy and natural resources that endanger the life of the planet.

Neotropical biodiversity is the result of millions of years of continuous evolution and interactions of species, populations communities and ecosystems. For example, where can we find elsewhere on the planet Earth such interactions between rivers and inundated forests on the scale that occurs in the Amazon basin?

This capacity of permanent and sustainable evolutive processes is what makes it worthwhile protecting neotropical biodiversity.

How can we conciliate economic development, biodiversity conservation, and preservation of the dynamic processes that sustain neotropical ecosystems and their life? There is no doubt that scientific knowledge is a fundamental component of the whole approach. To understand the "natural economy" (as opposed to the market economy) and to provide a basis for development without threatening biodiversity is an enormous task.

Science and technology applied to the neotropics and to the knowledge of processes could help to find the way out of this present equation economic development $=$ biodiversity extinction.

Homo sapiens as Wilson (2002) states, has become a "geophysical force": this could be used as a basis for new and innovative approaches to neotropical conservation 
and rational exploitation and help to remove the concept of geophysical force $=$ destruction. Can we change this trend in due time?

\section{References}

ALHO, JCR., 2008. Biodiversity of the Pantanal: Response to seasonal flooding regime and to environmental degradation. Braz. J. Biol. = Rev. Bras. Biol., vol. 68 no. 4 (Supl.). (In press).

COSTANZA, R., D’ARGE, Ralph; Groot,Rudolf; Farber, Stephen; Grasso, Monica; Hannon, Bruce; Limburg, Karin; Naeem, Shahid; O'Neil, Robert, Paruelo, Jose, Raskin,Robert; Sutton, Paul and Van Den Belt, Marjan. 1997. The value of the world's ecosystems services and natural capital. Nature. vol. 387, p. 253-260.

DUMONT. H., 2005. Biodiversity: a resource with a monetary value? Hydrobiologia, vol. 542, no. 1, p. 114-14.

GUIMARÃES, ICV. and TOLEDO, RM., 2008. Deforestation and threats to the biodiversity of Amazonia. Braz. J. Biol. $=$ Rev. Bras. Biol., vol. 68, no. 4 (Supl.). (In press).

HAFFER, J., 2008. Hypothesis to explain the origin of species in Amazonia. Braz. J. Biol. = Rev. Brás. Biol., vol. 68, no. 4 (Supl.). (In press).
MARENGO JA., 2007. Mudanças climáticas globais e seus efeits sobre a biodiversidade - Caracterização do clima atual e definição das alterações climáticas para o território brasileiro ao longo do Século XXI (Segunda Edicao). 2. ed. Brasilia: Ministerio do Meio Ambiente. vol. 1, 214 p.

-, 2008. Água e mudanças climáticas. São Paulo: USP. Dossiê Água IEA USP. p. 83-96.

MARGALEF, R., 1998. Our Biosphere. Excellence in Ecology. O.Kinne C (Series Editor). Oldendorf, Luhe, Germany. 176 p.

MILLENIUM ECOSYSTEM ASSESSMENT, 2003. Ecosystems and Human Well Being: a framework for assessment. Island: Island Press. 245 p.

WILSON, EO., 2002. The future of life. New York: A.A. Knopf. $328 \mathrm{p}$.

-, 2008. O maior patrimônio vivo do planeta. Veja, setembro 2008, edição especial 40 anos, p. 228-229.

ZALEWSKI, M., 2007. Ecohydrology in the face of the anthropocene. Ecohydrology and Hydrobiology, vol. 7, no. 2, p. $99-100$. 